Published in final edited form as:

Energy Policy. 2014 April 1; 67: 713-726. doi:10.1016/j.enpol.2013.11.068.

\title{
Land Use Change, Fuel Use and Respiratory Health in Uganda
}

\author{
Pamela Jagger ${ }^{a},{ }^{*}$ and Gerald Shively ${ }^{\mathrm{b}, 1}$ \\ aDepartment of Public Policy and Carolina Population Center, University of North Carolina at \\ Chapel Hill, CB\#8120 East University Square Chapel Hill, NC, USA 27599-3435
}

${ }^{b}$ Department of Agricultural Economics, Purdue University, 403 West State Street, West Lafayette, IN, USA 47907

\begin{abstract}
This paper examines how biomass supply and consumption are affected by land use change in Uganda. We find that between 2007 and 2012 there was a 22\% reduction in fuelwood sourced from proximate forests, and an $18 \%$ increase in fuelwood sourced from fallows and other areas with lower biomass availability and quality. We estimate a series of panel regression models and find that deforestation has a negative effect on total fuel consumed. We also find that access to forests, whether through ownership or proximity, plays a large role in determining fuel use. We then explore whether patterns of biomass fuel consumption are related to the incidence of acute respiratory infection using a cross-sectional data set of 1209 women and 598 children. We find a positive and significant relationship between ARI and the quantity of fuelwood from non-forest areas; a 100 kilogram increase in fuelwood sourced from a non-forest area results in a $2.4 \%$ increase in the incidence of ARI for children. We find the inverse effect of increased reliance on crop residues. As deforestation reduces the availability of high quality fuelwood, rural households may experience higher incidence of health problems associated with exposure to biomass burning.
\end{abstract}

\section{Keywords}

deforestation; fuelwood; Africa

\section{Introduction}

Fuel and cooking technology choices in the developing world are garnering increased attention in the wake of new research about the health impacts of exposure to smoke from burning biomass fuels (Ezzati et al., 2002; Fullerton et al., 2008; Lim et al., 2012; Mishra et al., 2004; Smith, 2000; Sreeramareddy et al., 2011). At the same time, biomass smoke or "black carbon" has been implicated in regional and global climate change (Ramanathan and Carmichael, 2008; UNEP and WMO, 2011). ${ }^{2}$ Public investments directed at reducing

\footnotetext{
(C) 2013 Elsevier Ltd. All rights reserved

*Corresponding author. Tel.: +1 919962 2151; fax: +1 919962 9999. pjagger@unc.edu. ${ }^{1}$ Tel.: +01 7654944218 .

shivelyg@purdue.edu
}

Publisher's Disclaimer: This is a PDF file of an unedited manuscript that has been accepted for publication. As a service to our customers we are providing this early version of the manuscript. The manuscript will undergo copyediting, typesetting, and review of the resulting proof before it is published in its final citable form. Please note that during the production process errors may be discovered which could affect the content, and all legal disclaimers that apply to the journal pertain.

${ }^{2}$ The terms biomass fuels, solid fuels and traditional fuels are used interchangeably in the literature. These fuels are differentiated from modern liquid fuels (e.g. paraffin, kerosene, liquid petroleum gas) which are more efficient and considered to be less damaging to human health. 
household emissions from biomass burning are viewed as potentially useful because actions relating to fuel and cooking technology could have large and immediate impacts on both local health and greenhouse gas pollutants (Kandlikar et al., 2009; Smith and Balakrishnan, 2002; Smith et al., 2009). Donors, NGOs and organizations such as the Global Alliance for Clean Cookstoves (www.cleancookstoves.org) are supporting increased public investment in addressing fuel use and cooking technology options in developing countries.

Three billion people, or roughly $40 \%$ of the world's population are completely dependent on biomass as their primary fuel for cooking and heating (Foell et al., 2011; Grieshop et al., 2011; Openshaw, 2011; Vlosky and Smithhart, 2011; WHO, 2006). Barnes et al., (2002) estimate that the absolute number of people dependent on biomass fuels will increase through 2030, suggesting that policy makers should be attentive to factors that influence the supply, demand and distribution of biomass fuels. These trends are particularly striking in sub-Saharan Africa where the consumption of biomass fuels is higher than in any other region (Arnold et al., 2005; Bailis et al., 2005; Nkambwe and Sekhwela, 2006; Vlosky and Smithhart, 2011). East Africa is particularly dependent on biomass fuels; more than $95 \%$ of the populations of Burundi, Ethiopia, Rwanda, Tanzania and Uganda use solid fuels for cooking and heating (WHO, 2006; GACC, 2013). ${ }^{3}$ This degree of dependence places the region in sharp relief for investigating the environmental and health impacts of using biomass for energy purposes.

While demand for biomass fuels continues to grow in sub-Saharan Africa, rapid land use change is reducing the supply of high quality biomass and leading individuals to shift collection away from forests toward locations such as farmlands and fallows that typically yield much lower per hectare quantities of biomass (Ahrends et al., 2010; DeFries et al., 2010). Such changes in the supply of locally-available biomass fuels have implications for household fuel use and the exposure of women and children to harmful gasses and particulate matter associated with the incomplete combustion of lower quality or wet biomass. These changes also have indirect effects on how women and children use their time, the number of meals that are cooked, and the types of foods that are prepared, which can affect overall food security as well as health and nutrition outcomes. Fuelwood scarcities may lead households to obtain lower quality wood, change their cooking patterns, or work harder to collect wood (Brouwer et al., 1997; Lipper, 2000). Nevertheless, how land use change affects the types, quantities and sources of biomass fuels, and how those in turn affect health and welfare outcomes is poorly understood.

This paper focuses on two questions relevant to these global concerns. First, we ask whether land use change in Uganda is precipitating changes in household fuel portfolios. We do this by measuring the relative shares of different types of fuels consumed by households over time. A typical fuel portfolio in rural Uganda includes fuelwood of varying qualities, charcoal and crop residues. In addition to cataloging the types of fuels being used, we also measure the quantities and identify the sources of these fuels, in particular whether fuels are being collected from forests or elsewhere. We hypothesize that forest degradation and loss may be leading households to substitute fuel from non-forest environments, including fallows and bush land, in place of higher-quality forest-based fuels. We also hypothesize that forest degradation and loss reduce overall household fuel consumption. To test these conjectures we use a balanced panel of data from 451 households in western Uganda, collected in 2007 and 2012. These data include detailed information about the types, quantities and qualities of biomass fuels consumed, and allow us to measure changes in these features over time and how they are correlated with land use change.

\footnotetext{
${ }^{3}$ The Food and Agriculture Organization of the United Nations (FAO) estimates that, in 2008, 6.15 billion square meters of fuelwood were harvested in Africa, more than one-third of which were in East Africa (FAO, 2011).
} 
Our second research question focuses on how patterns of biomass fuel consumption affect health outcomes for women and children. Specifically we test two hypotheses. First we study whether the quantity of fuel used by a household is correlated with the incidence of acute respiratory infection (ARI). Second, we test whether the incidence of ARI is correlated with lower quality biomass fuels (sourced outside of forests). For this stage of the analysis we use data from the 2012 wave of our survey which recorded symptoms typical of ARI among children under age 5 and adults -typically women - involved in cooking. ${ }^{4}$ Our sample includes 1,823 women and children that were residing within the 555 households included in the 2012 survey. We estimate a series of regressions that take into account household-level characteristics known to influence health outcomes and compute the marginal effects of changes in the quantities and types of fuels used on the reported incidence of ARI.

Our findings confirm that rapid deforestation is changing the fuel portfolios of rural households. We find evidence of a major shift to fuelwood sourced from non-forest areas including fallows, agricultural plots and bush lands. Crop residues are also increasingly common. We also find evidence of a link between biomass source and the incidence of ARI. Controlling for other characteristics of the household, individuals living in households that sourced their fuel from forests had lower overall rates of ARI, compared with those living in households that are more dependent on fuel from non-forest areas. Our findings confirm that deforestation plays a role in altering household fuel portfolios and suggests that ongoing changes in fuel use have implications for human health.

\section{Linking biomass supply to health outcomes}

Our analysis rests on assumptions about a two-stage causal pathway. In the first stage, forest quality, forest proximity and overall patterns of land use influence fuel availability; in the second stage, the types and quantities of fuels used by households influence respiratory health outcomes for women and children.

\subsection{Land use and biomass availability}

With almost half of the global population relying on woody biomass as their primary fuel source, the implications of land use change that results in reductions in biomass availability and quality are hard to ignore. Over the past several decades, researchers have explored the links between fuel use, deforestation, and energy poverty in developing countries, largely focusing on the hypothesis that biomass fuel harvesting is a driver of deforestation and degradation. Research addressing the sustainable harvest of fuelwood and other sources of woody biomass falls into two groups: the first asserting that fuelwood harvesting is a major contributor to global forest degradation and has severe negative environmental ramifications (e.g., Eckholm, 1975); and the second asserting that the impacts of non-commercial fuelwood harvesting are not necessarily negative, and that harvesting can sometimes even improve environmental robustness (Arnold et al., 2005; Foley et al. 2005; Masera et al., 2006; Nkambwe and Sekhwela, 2006; Naughton-Treves et al., 2007; Openshaw, 2011). In many rural areas, gathering wood for fuel has been shown to not have a detrimental impact on land, but in more densely populated areas where natural resources are less abundant, the demand for land and resources can lead to higher degree of degradation (Nkambwe and Sekjwela, 2006).

Several studies have noted the lack of information about fuelwood harvesting practices, fuelwood quality, and the dynamics of fuelwood use, specifically with respect to woody

\footnotetext{
${ }^{4}$ Ninety-eight $\%$ of cooks in the sample are female. Henceforth we use the terms "women" and "cooks" synonymously.
} 
biomass availability within different land uses (Foley, 2001; Hiemstra-van der Horst and Havorka, 2009; Masera et al., 2006; Smeets and Faaij, 2007). For example, much of the material like fallen branches, dead wood and material from shrubs that serve as an important sources of fuel for many rural populations are not necessarily included in overall assessments of biomass stocks. Furthermore, it is difficult to synthesize what information is available due to the range of methods employed to characterize the stock of woody biomass throughout tropical regions. For example, biomass inventories frequently ignore biomass stocks outside forest regions (Foley, 2001; Smeets and Faiij, 2007; Turyareeba, Drichi and UNEP, 2001). Our study seeks to quantify and characterize biomass fuel use by rural households in Uganda. We view this as an important contribution toward understanding the role of biomass supply in household decisions regarding fuel use.

\subsection{Health Impacts of Woody Biomass Burning}

The World Health Organization (WHO) estimates that as many as 2.5 million women and young children die prematurely each year from respiratory ailments caused by inhalation of smoke from open biomass-burning stoves (Arnold et al., 2005). The most common health issues associated with household air pollution are acute infections of the lower respiratory tract, chronic obstructive pulmonary disease, lung cancer, asthma, cataracts and tuberculosis (WHO, 2006). ARIs, which can result from inhalation of particulate matter and other toxins, are responsible for as much as $6 \%$ of global disease and mortality, predominantly in lessdeveloped nations (Ezzati and Kammen, 2001). ${ }^{5}$ Women, as the primary cooks and caretakers of most households, are especially vulnerable. Not only do they bear the largest health burdens associated with emissions from woody biomass, they also lose time and suffer physical consequences from gathering and transporting biomass fuels (Foell et al., 2011). Young children exposed to high concentrations carbon monoxide, polycyclic aromatic hydrocarbons, and particulate matter are two to three times more likely to develop acute lower respiratory tract infections than children in households using cleaner fuels (Fullerton et al., 2008). In 2000, 51\% of child deaths and $63 \%$ of adult female deaths in subSaharan Africa were attributable to pollution caused by household burning of biomass (Bailis et al., 2005).

Research on the determinants of fuel and cooking technology use has been heavily focused on demand side determinants including income, household size and education levels (Chen et al., 2006; Gupta and Kohlin, 2006; Heltberg, 2004; Kavi Kumar and Viswanathan, 2007). Many studies are predicated on the energy ladder hypothesis which states that demand for fuelwood, an inferior good, decreases as income increases, while that for gas and liquid fuels rises with income. ${ }^{6}$ Econometric studies of household fuelwood demand generally find that income elasticities are negative, validating the energy ladder hypothesis (Gundimeda and Kohlin, 2008). However, in most studies, the effect appears to be small and statistically weak, suggesting that factors other than income may be driving household decisions (Arnold et al., 2005; Baland et al., 2010; Barnes et al., 2002),

A number of case studies on fuel use include distance to forest, or time spent on fuel collection as covariates, and find that as distance to forest or time to forest increases, charcoal consumption increases (i.e., relative to fuel wood consumption) (Chen et al., 2005; Jumbe and Angelsen, 2010). Other meso-level variables considered in case studies include

\footnotetext{
5 The health impacts from burning woody biomass in an unventilated indoor environment are considered more harmful than secondhand tobacco smoke or industrial emissions (Dosier, 2004), and have been estimated in some cases to exceed the equivalent of smoking two packages of cigarettes every day (WHO 2006). Exposure can exceed the U.S. Environmental Protection Agency's recommended exposure levels by as much as a hundred times (Bailis et al., 2009).

${ }^{6}$ For example, our own regression results based on nationally representative data from the 2006 Uganda National Household Survey suggest an income elasticity of demand for charcoal of -0.05 , compared with 0.36 for liquid fuels.
} 
altitude and forest area per person (Turker et al., 2001); own and cross price elasticities for different fuels (Gupta and KIohlin, 2006); presence of community-based institutions focused on sustainable forest management (Jumbe and Angelsen, 2010); community coordination and public provision of services (Macht et al. 2007; Pandey and Yamada, 1992; Pattanayak and Pfaff, 2009; Sinton et al., 2004); convenience and reliability of fuel supply (Gupta and Kohlin, 2006); perception of pollution (Gupta and Kohlin, 2006); credit market access (Edwards and Langpap, 2005); and population growth rates (Arnold et al., 2005; Baland et al., 2010). However, few studies model a comprehensive set of both the supply and demand side determinants of fuel and technology use, and most studies are focused on relatively small geographic areas, making it difficult to include heterogeneous meso- and macro-level variables. A recent study by Rehfuess et al., (2010) used hierarchical Baysian spatial models to quantify heterogeneity between regions and districts, and found that fuel choice in three SSA countries was heavily influenced by neighborhood effects and place. These findings suggest that the sharp focus on household-level determinants and case studies provides only a partial picture of the determinants of fuel and technology use. This study aims to develop and test a model that includes both micro- and meso-level variables with a specific focus on the supply of biomass fuels.

\section{Study area, sampling and empirical approach}

\subsection{Study area}

The study villages fall within seven districts (Figure 1) in Uganda's west central region. The study area spans a relatively large geographic area with roughly 300 kilometers between the southern and northern most villages. The dominant cropping systems include maize, bananas, and coffee. Rainfall is moderate and altitude ranges from 1000 to 1800 meters above sea level. Smallholders keep cattle, small ruminants and poultry in extensively managed crop-pasture systems (MAAIF, 1995; Nzita and Niwampa, 1993). Land holdings in the area are relatively small, averaging 2.65 hectares per household. Three land tenure systems are common: customary, freehold and mailo. The Bugoma and Budongo study area have undergone rapid settlement over the past 10 years largely by Bakiga migrants from land scarce Kabale District in southwestern Uganda. Livelihood strategies in the study area fall into five main categories: agriculture, livestock husbandry, collection of forest and wild products, wage labor and self-employment (i.e. small business). The labor force is relatively stationary, suggesting few opportunities for households to generate remittances.

Deforestation is well known to be a major environmental issue in both western Uganda. Forests outside of gazetted areas (i.e. national parks and central forest reserves) face serious threat (Nsita, 2005). In-migration and land disputes are contributing factors to high rates of deforestation, and degraded forest mosaics are common, particularly in areas with relatively good market access. Clearing forest and establishing perennial agricultural crops including bananas and coffee is the most expedient and reliable way to establish de facto property rights (Acworth, 2005). A large share of the sawn wood produced for Uganda's domestic timber markets is also sourced from this area, which contributes to forest degradation. Estimates from several forest agency documents suggest that approximately 50\% of tropical high forest on private land is degraded, as compared with $17 \%$ in protected areas (Nsita, 2005).

In Uganda, land cover types and woody biomass were not formally documented until the National Biomass Study in 1996. The biomass study divided land into gazetted and ungazetted areas and provided estimates of total available woody biomass by category of land use. Approximately $36 \%$ of Uganda's available woody biomass is found in subsistence farmlands, $28 \%$ in woodlands, $14 \%$ in tropical high forests, $11 \%$ in grasslands, and the remaining $11 \%$ between hardwood plantations, built areas, bush lands, large-scale farmland, 
softwood plantations, and degraded tropical high forests. However, on a per hectares basis, tropical high forest provides by far the highest amounts of available woody biomass (224 t/ ha) (Table 1). Degraded tropical high forest provides approximately half the per hectare woody biomass of a fully stocked forest; subsistence crop land provides only $12.7 \mathrm{t} / \mathrm{ha}$.

\subsection{Sampling and data collection}

The data for this study come from two rounds of a household panel survey conducted in 2007 and 2012. The initial sample was drawn from a randomly selected set of villages in the forest mosaics of west central Uganda $(\mathrm{N}=18) .{ }^{7}$ Within each village a random sample of 30 households was selected to participate in the household interview $(\mathrm{N}=540)$. The second round of the panel attempted to follow these households. There was a relatively low rate of attrition from the sample. The balanced panel includes 451 households. The most common reasons for attrition were either death of the household head or out-migration. ${ }^{8}$ The total population of the thirteen sub-counties in which data were collected was 253,587 in 2002 (UBOS, 2006). Our sample includes approximately 3,600 individuals, or roughly $1.4 \%$ of the total population of the 13 sub-counties.

\subsection{Remote sensing data and analysis}

We obtained freely available data from the online data pool at NASA's Land Processes Distributed Active Archive Center (LP DAAC) where satellite data are classified into land cover types at 500-meter resolution with quality control and assurance provided by MODIS Land Evaluation Strategy. ${ }^{9}, 10$ We selected averaged yearly land cover data for three years of interest $(2003,2007$ and 2011) corresponding with the time frame relevant to our socioeconomic panel dataset collected in field sites in Western Uganda. The V005 and V051 data set span the temporal range of 2001-2011. Land cover classifications existed for fourteen different land cover types. Due to our specific interest in vegetated forest and savanna conversion to cropland, we reclassified the land cover types into broader categories including forest, woody savanna and savanna to denote varying amounts of biomass availability for household fuel use. ${ }^{11}$

After downloading the land cover type data and reclassifying the forest, woody savanna and savanna into broader categories, we identified major land cover transitions of interest. Using raster algebra, were able to identify $500 \times 500 \mathrm{~m}$ pixels of land that were forestland in year 2003 and track these individual pixels in the subsequent years of our study -2007 and 2011. By combining raster algebra and the reclassify tool in the Spatial Analyst Toolbox, we were able to create new land cover classes. We defined transition classes where a pixel of land that was forest in year $\mathrm{t}-1$ and cropland in year $\mathrm{t}$ would join a newly created land cover class, i.e. "Forest->Cropland." These transitions were created to measure cropland conversion, forest degradation (Forest->Woody Savanna) and areas of limited change.

\footnotetext{
${ }^{7}$ In the Budongo site we augmented the 2007 sample by randomly selecting households to participate. Our aim was to sample 40 households per village. In the Rwenzori and Bugoma sites we surveyed only those households that participated in the 2007 survey. ${ }^{8}$ Most migrants moved to other rural areas, often within the same district.

${ }_{9}^{9}$ MODIS/Terra+Aqua Land Cover Type Yearly L3 Global 500m SIN Grid. NASA Land Processes Distributed Active Archive Center (LP DAAC). ASTER L1B. USGS/Earth Resources Observation and Science (EROS) Center, Sioux Falls, South Dakota. 2001.

${ }^{10} \mathrm{We}$ chose to use land cover type grids from the MODIS-MCD12Q1 product due to its potential for the rapid assessment of land cover change, free availability, and performance at 500-m resolution. Vintrou et al., (2012) found the MCD12Q1 land cover product achieved higher accuracy in mapping cropland compared with alternative existing global land products (GLC2000 Africa, GLOBCOVER, and ECOCLIMAP-II). Friedl et al. (2010) detail the decision-tree algorithm model employed to classify land cover types and crossvalidation analysis for accuracy on a yearly scale. The land cover product provides data that aggregates 8-day values with 32-day averages and uses a weighted averaging procedure for quality assurance. This alleviates concern for seasonal variation bias in the data, though data for savanna and woody savanna lands are found to be less accurate than data for forest and cropland identifications.

${ }^{11}$ Evergreen Needleleaf, Evergreen Broadleaf, Deciduous Needleleaf, Deciduous Broadleaf, and Mixed forest were all reclassified into general "Forest" land cover type. Open and closed shrublands were reclassified into general "Shrublands" land cover type.
} 
Because the land cover data are closely tied to the panel survey data collected at 18 villages, we then demarcated a 5-kilometer buffer zone circling each village and used the Tabulate Area function in the Spatial Analyst Toolbox to count the number of pixels of each land cover transition class for each village for three periods: 2003-2007; 2007-2011; and 20032011. ${ }^{12}$ Each classification denotes a varied amount of biomass availability for household fuel use. Overall classification accuracy is estimated in the MCD12Q1 product to be $75 \%$ through cross-validation analysis (Friedl et al., 2010). Our analysis considered relative changes in land cover type within the dataset, for accuracy and to avoid classification errors (Pfeifer et al., 2012). Additionally we asked a series of qualitative survey questions on forest cover and forest quality in our household surveys to assess local perceptions of the rate of forest conversion to corroborate our results.

\subsection{Analysis}

Our first question is aimed at understanding the composition and determinants of fuel use over time. By combining remote sensing analysis with descriptive statistics of the type, quantity and location of harvest of biomass fuels we infer the impact of rapid deforestation and forest degradation on fuel use portfolios. We estimate the volumes of fuelwood, charcoal and crop residues harvested by individual households from forests and non-forest environments, and use these to construct measures of household fuel portfolios. We present descriptive statistics to explore the variation in fuel use across time. Finally, we estimate a random effect panel regression model to explore whether land use change is associated with changes in fuel use over time in fuel use over time. ${ }^{13}$

To explore the relationship between biomass fuel use and ARI we estimate a series of probit regression models using 2012 data and individuals at the unit of analysis. The dependent variable in these models is a binary indicator of ARI, which equals one if the individual reported combined symptoms of cough and difficulty breathing and zero otherwise. We estimated three models, one for the full sample of 1,823 individuals, a second for only children, and a third for only adults. The volume of biomass fuels consumed by the household are the independent variables of interest (i.e. volume of fuelwood from forest, volume of charcoal, volume of fuelwood from non-forest areas and volume of crop residues. In our analysis the maintained assumption is that fuel from forests is of higher quality than fuel from non-forest areas. This assumption in part rests on data (Table 1) which highlight the scarcity of biomass fuels in non-forest areas. Our unit of observation is the individual, but we control for a number of household-level characteristics including total income, the role of the individual (first, second or third youngest; primary, secondary or tertiary cook), extent of ventilation in the cooking setting, use of improved stove, household size, and age, gender and education level of the household head. We also include dummy variables for the study site as an indicator of broad differences in regional economic, demographic and biophysical conditions. For each of our models we estimate marginal effects. Descriptive statistics for all variables included in the regression models are summarized in Appendix A.

\section{Results}

\subsection{Land use change and biomass consumption}

Land cover and land cover change analysis indicating the area of forest (predominantly tropical high forest), woody savannah, savannah and cropland within a $5 \mathrm{~km}$ radius of

\footnotetext{
${ }^{12}$ Our data, as well as data collected and analyzed by Khundi et al. (2011) from a different but similar site in Uganda indicate that 95 percent of sample respondents lived within $5 \mathrm{~km}$ of accessible forests. We therefore use a $5 \mathrm{~km}$ radius from village centroids as we feel this represents a reasonably representative distance for rural people to walk to collect fuelwood in Uganda.

${ }^{13}$ We adjust monetary amounts from 2007 to be comparable with 2012 data using the official average annual inflation rate between 2007 and 2011 of $10 \%$.
} 
village centroids are summarized in Table 3. We consider data for two time periods: 20032007 representing the time period prior to our 2007 socioeconomic data collection, and 2007-2011 representing the period prior to our 2012 socioeconomic data collection. ${ }^{14}$ Our expectation is that land use trends in the years immediately prior to our socioeconomic data collection strongly influence the location where fuel is sourced as well as the types and quantities of fuel used.

Our analysis suggests that both deforestation and forest degradation are taking place. Our remote sensing analysis reveals considerable changes in land use, with forest cover falling by $14 \%$ from $43 \%$ in 2003 to $29 \%$ in 2011. Between 2003 and 2011 this represents a percent change of $-36.3 \%$. During the same time period, cropland increased by $15.1 \%$ from $37.4 \%$ to 52.5 percent representing a percent change of $+40.4 \%$ in cropland. Overall fluctuations in woody savannah and savannah were not very large, but are suggestive of forest degradation where forest transitions to woody savannah or woody savannah transitions to savannah.

We note considerable variation in study areas with the Rwenzori site experiencing increases in forest cover, largely due to effective forest management in communities adjacent to Rwenzori Mountains National Park, and also due to the increased presence of woodlots and tree plantations between 2003 and 2011. The most significant forest loss was observed in the Bugoma site, where the percent change in forest cover was $-78.4 \%$, and the percent change in land classified as cropland was $+154.8 \%$. In the Bugoma site the area classified as woody savannah also increased considerably (26.3\% to 41.8\%) between 2003 and 2007 during the time of most pronounced forest cover loss, suggesting considerable forest degradation in this area. Investment in woodlots and plantations is best reflected in the Budongo site where forest cover declined by $11.9 \%$ between 2003 and 2007 and then increased by $7.7 \%$ between 2007 and 2011. Opposite trends were observed for cropland which increased and then declined by similar proportions over the 2003-2007 and 2007-2011 periods. Maps illustrating the extent of land cover change within the village buffers are presented in Figure 2.

To corroborate our remote sensing analysis of land use change we asked households about changes in forest cover and quality for two time periods, 2003-2007 and 2007-2012.

Respondents indicated major declines in both time periods in general forest cover and specific closed-canopy forest area. They also reported increases in flooding, soil erosion and water availability, which are consistent with observed patterns of deforestation. Indicators of degradation include changes in the diversity of tree, animal and bird species, the number of large trees and water quality. All indicators point to a trend of considerable forest degradation in recent years, particularly for privately-owned and community-managed forests in the study area.

An important question for our analysis is what drives deforestation and degradation in our study area. In particular, to verify our hypothesized causal chain, we need to know that fuel collection by rural households is not a major driver of deforestation or degradation. Both key informant interviews with village leaders and forest officials, as well as data collected in 2007 on area of forest cleared and the motivations for forest clearing verify that agricultural production and timber harvesting (Jagger et al. 2012) are the main contributors to deforestation and degradation. We assert that fuel harvesting plays a negligible role in forest degradation in the study area. Technology constraints (i.e. lack of saws) prohibit households from harvesting standing trees for fuel, and charcoal production is largely a by-product of the land conversion process; often produced in tandem with land clearing for crop and livestock production (Shively et al. 2011).

\footnotetext{
${ }^{14}$ More recent remote sensing images were not yet available at the time of the study.
} 
We collected data on the type, volume and source (i.e. location of harvest) of biomass fuels consumed by households in 2007 and 2012 (Table 4). ${ }^{15}$ We present data for biomass fuels obtained from forests as well as fuels obtained from non-forest areas including fallows, agricultural lands, bush land etc. Forest fuels include fuelwood and charcoal. Fuels obtained from outside forests include fuelwood sourced from fallows, agricultural lands, and bush lands, and crop residues. ${ }^{16}$ In $2007,75.2 \%$ of fuelwood was sourced from forests as compared with $21.2 \%$ sourced from areas outside of forests. When we compare these data with data from 2012 we find that there has been a significant change in where households are sourcing fuelwood from. Roughly half of the fuelwood the households in our sample use comes from forests, and the share of fuelwood sourced from areas other than forests has increased to $40.4 \%$ in 2012.

We do not observe major changes in the quantities of charcoal used by rural households. While charcoal is often produced as a byproduct of forest clearing, the majority of charcoal is sold to traders who market it in Kampala or other major urban areas (Khundi et al., 2011; Shively et al., 2011). Finally we observe a significant increase in the use of crop residues as fuels. In 2007, households were using an average of $2.7 \mathrm{kgs}$ of crop residues per quarter. However, by 2012, households were using approximately $31.6 \mathrm{kgs}$ of crop residues over a three month period, accounting for $6.5 \%$ of total fuel use in the household. These trends generally hold for the three study areas but with varying increases in dependence on fuel wood from non-forest areas. In 2012 in the Bugoma site with the highest rates of deforestation, almost half of total fuel was sourced from non-forest areas as compared with $38 \%$ in the Budongo site and 34\% in the Rwenzori site. In the Bugoma and Rwenzori sites dependence on both non-forest fuels and crop residues increased significantly from 2007 levels. We do not observe major differences between the matched sample and broader sample in any of the study areas.

With respect to the total volume of fuels used, we find that total fuel consumption per household has increased from $474 \mathrm{kgs}$ over a three month period, to $500 \mathrm{kgs}$ for the matched sample of households during the same quarter. Fuelwood (forest fuel + non forest fuel) accounts for roughly $12 \mathrm{kgs}$ of the increase, with crop residues explaining the remainder. Finally, we find significant changes in the distance that households travel to the nearest forest. In 2007, the average time to walk to the nearest forest was 34 minutes. By 2012, the average time increased to 45 minutes for the matched sample of households. These findings are consistent with our remote sensing analysis confirming that deforestation is increasing the distance people must travel to collect high quality fuelwood.

Results of a series of panel regression models exploring the land use change as a determinant of fuel use are presented in Table 4. We find that total fuel declines when there are large transitions from forest or woody savannah to cropland, all else equal. We do not find statistically significant relationship between the quantity of fuelwood sourced from forests and land use change variables that reflect deforestation or forest degradation. We do find a strong negative relationship between the volume of fuelwood from non-forest areas and areas with large transitions from forest to woody savannah. The inverse (but not statistically significant relationship holds for fuelwood from forests, suggesting that transitioning from forest to woody savannah actually increases the amount of fuelwood collected from forests rather than decreases it. We also find evidence of substitution between forest fuelwood and non-forest fuelwood. Households that collect large quantities of

${ }^{15}$ Data represent one quarter of the year, roughly May-July for the Bugoma and Budongo field sites. The data from the Rwenzori field sites represents household activity for October - December for the Rwenzori site. Data were collected at the same time to avoid issues of seasonal bias in the reporting of volume and value estimates.

16 Maize cobs, bean husks and millet stalks are the most commonly used crop residues in the study area. 
fuelwood from forests are less likely to harvest fuelwood from non-forest areas and visaversa.

We also explored household-level covariates and find that forest ownership has a strong positive relationship on the quantity of fuel harvested from forests. Household size is also strongly positively associated with the volume of fuelwood used, but negatively associated with the use of crop residues. Income plays an important role in all of our models.

Households with higher incomes use larger quantities of fuel. This result is statistically significant for all models except the model focused on volume of crop residues used. Increasing distance from forest is associated with lower volumes of fuel overall, and also with lower volumes of fuelwood from both forest and non-forest sources. Distance from forest is positively correlated with the use of crop residues. This finding combined with the importance of household ownership of forests and fuel use implies household-level access to forests plays an important in determining who is able to access high vs. low quality fuels.

\subsection{Biomass fuel portfolios and health outcomes}

We now turn to the linkage between fuel use and health outcomes. Our hypothesis is that the quantity and quality of biomass fuels used in households may influence health outcomes associated with exposure to smoke from biomass burning. We hypothesize that both quantity and quality are determinants of overall exposure to carbon monoxide and particulate matter, which in turn influence respiratory health outcomes. Our interest in this question is to connect our findings about land use change and fuel supply to health outcomes.

To assess whether individuals experienced acute respiratory infection we collected data on self-reported symptoms of ARI including presence of cough, and difficulty breathing by replicating questions from the Uganda Demographic and Health Survey (DHS) designed to measure indicators of ARI. We collected these data for the three youngest children under 5 years, and for the primary, secondary and tertiary cooks in each household. While these individual indicators are not unique to ARI, when observed in combination they are strongly indicative of ARI. Data for ARI involved recall over the past 14 days. This time frame overlaps with our recall data on biomass consumption which includes all biomass consumed by the household during the past 30 days. We assume that fuel consumed by the household in the several weeks immediately prior to and during the 14 day recall period for health outcomes accurately maps fuel consumption patterns to health outcomes.

Our data suggest a relatively high incidence of ARI for children under 5 (34\%). There is a strong negative correlation between age and presence of symptoms of ARI for children; among youngest children $38 \%$ exhibited symptoms of ARI. Reports of ARI symptoms decreased with age; $30 \%$ of second youngest children and $21 \%$ of third youngest children had symptoms of ARI. In our adult population $7 \%$ of women reported having symptoms of ARI within two weeks prior to the interview. Primary cooks had the highest incidence (12 $\%)$ and dramatic reductions in symptoms of ARI were documented for secondary and tertiary cooks ( 5 and $2 \%$ respectively).

We are specifically interested in the quantity and source of biomass that households are consuming, and whether consumption of fuels of different types and from different land uses might have an effect on observed health outcomes. ${ }^{17}$ Our preliminary investigation of the correlation between the volume and type of fuel used at the household level and reports of ARI infection suggests that there are few significant differences between fuelwood sourced from forests, charcoal consumption and ARI outcomes (Table 5). We do observe statistically

${ }^{17}$ Note that by definition crop residues are sources from non-forest lands. All charcoal consumed in the households in our sample was produced from forests or woodlands allowing us to categorize it as forest fuel. 
significant differences between the quantity of non-forest fuelwood and symptoms of ARI, with a particularly strong effect for children under 5. Children in households that use larger quantities of non-forest fuelwood have a higher incidence of ARI. We find the opposite relationship between crop residues and ARI; that is individuals in households that use larger quantities of crop residues are less likely to have symptoms of ARI.

We explore the role of biomass fuels in determining ARI by running a series of probit regression models (Table 6). The primary focus of these models is to identify the effect of different types and quantities of fuels in explaining ARI outcomes when controlling for a number of important covariates including household income, the role of the individual in the household (i.e. birth order of children under 5; primary, secondary or tertiary cook), the cooking setting (i.e. outdoors, in a well-ventilated kitchen or in a poorly-ventilated kitchen), whether the household uses an improved stove, household demographic characteristics (i.e. size of household, age, education and gender of head), and study site.

We find support for our hypothesis that fuel sourced from non-forest areas is associated with a higher incidence of ARI, particularly for children. We estimate that a $100 \mathrm{~kg}$ increase in fuelwood from non-forest areas increases the likelihood of ARI by $2.4 \%$ for children. To put this number in perspective it takes roughly 5-7 kgs of fuelwood to cook a pot of beans on a three stone fire, so that one hundred kilograms of fuelwood represents between 15 and 20 cooked meals. Conversely we find a significant negative effect of crop residues on ARI. A $100 \mathrm{~kg}$ increase in crop residues is associated with a $3.9 \%$ decrease in the likelihood of ARI in children, and a $2.2 \%$ decrease in the likelihood of ARI for the full sample of adults and children. This could reflect a pattern in which relatively greater use of crop residues in a household reflects relatively higher agricultural yields and, therefore, better overall nutrition in those households.

We find a weakly statistically significant positive relationship between income and presence of ARI in children. A possible explanation for this is that better off households have more cooked meals. Thus being a child in such a household suggests increased exposure to biomass smoke. However, we do not find a significant result for adults. Being the youngest child in the household or being the primary cook is a strong determinant of ARI. Second and third youngest children are 6.8 and $16.0 \%$ less likely to have ARI than the youngest child. Our explanation for this is that the youngest child spends the most time with the mother, who is frequently the primary cook. We also observe a similar pattern for secondary and tertiary cook who would have far lower exposure to biomass smoke; they are 6.4 and $8.9 \%$ less likely to have ARI respectively. Surprisingly we find no evidence that either ventilation or cooking with an improved stove is significantly correlated with ARI outcomes. This likely reflects uniformly low levels of improved stoves and ventilation systems in the sample. Finally, household size plays a significant role as a determinant of ARI. We observe a significant and positive relationship between household size and ARI for the overall sample, and for children. For example, the addition of one person to the household increases the likelihood of ARI in children by $4.6 \%$. This likely reflects increased fuel consumption due to more mouths to feed. However, the sign on the squared term suggests a concave relationship and diminishing marginal effect as more people are added to the household.

\section{Conclusions}

We highlight two main findings from our analysis. First, we find that deforestation, motivated primarily by clearing land for agricultural production influences the type and source of biomass fuels used by rural households in Uganda. While our study area has experienced rapid deforestation, the rate of forest loss is not atypical of other parts of East Africa, particularly for forests outside of gazetted or protected areas. Specifically we find 
that the types and source of fuel used by rural households changed substantially between 2007 and 2012. Fuel from non-forest areas and crop residues became more commonly used increasing by $18 \%$ and $5 \%$ of total fuel supply respectively.

Our second major finding is that the source of biomass appears to be correlated with reported health outcomes. Specifically we find a higher incidence of ARI for households that are more heavily reliant on fuel sourced from non-forest areas, and a lower incidence of ARI among households that are more reliant on crop residues. Given that differences in total volumes of forest and non-forest fuels are small, we believe differences in fuel quality may be responsible, in part, for influencing negative health outcomes. This finding is particularly important in light of rapid deforestation and associated land use change, and potential constraints on future fuel supply.

\section{Policy recommendations}

Our findings suggest several points of entry for health and environmental policy interventions, particularly in the context of the global focus on clean cookstoves as a mechanism with high potential for both reducing household air pollution and mitigating climate change. If one assumes that the availability of modern fuels and cooking technologies for rural households in the region will continue to be limited, and that adoption will be slow, our findings provide prima facie evidence in favor of policies to promote the use of higher-quality biomass fuels AND more efficient cooking technologies. Until very recently tree planting was rare in the study area. To date, most tree planting initiatives in Uganda have focused on timber production and biodiversity enhancement (Omeja et al., 2011). Providing greater emphasis on tree planting for fuelwood could be an important strategy to support rural households currently relying on low quality solid fuels. While attention often focuses on fast growing fuelwood species such as pine and eucalyptus, recent experience with pigeon pea in southern Malawi suggests opportunities for food and fuel synergies; pigeon pea stalks are routinely used as fuel in areas where tree biomass has dwindled (Webb, 2011).

Our findings also suggest that the health, environment, and development research and policy communities should devote greater attention to the fuel component of cooking decisions. Distinctions between modern and solid fuels make little difference in countries with $95 \%$ dependence on solid fuels. More attention to the array of biomass fuels households are using, including disaggregating wood fuels into categories of low and high quality is warranted in order to generate a more complete and accurate understanding of the determinants of household air pollution. Our analysis also demonstrates the importance of tracking changes over time. Under current rates of deforestation in Uganda it is anticipated that all forests outside of protected areas will be converted to cropland by 2020. Our findings suggest that the inevitable search for fuelwood substitutes may have negative health effects increasing household air pollution as a risk factor for burden of disease in Uganda, and elsewhere in sub-Saharan Africa.

\section{Acknowledgments}

We are grateful to the following organizations for funding this research: the Global Nutrition Collaborative Research Support Program (NCRSP) of the Bureau of Economic Growth, Agriculture and Trade, U.S. Agency for International Development (USAID, Grant No: AID-OAA-10-00006); the Center for International Forestry Research; the Collective Action and Property Rights Initiative (CAPRi) of the Consultative Group on International Agricultural Research; the National Science Foundation (NSF, Grant No. DDIG 0622392); the Social Sciences and Humanities Research Council of Canada (SSHRC); the Social Science Research Council (SSRC); and the Sustainable Agriculture and Natural Resource Management Collaborative Research Support Program (SANREM CRSP, Grant No. EPP-A-00-04-00013-00). This research received support from the Eunice Kennedy Shriver National Institute of Child Health and Human Development (1K01HD073329-01). We are grateful to the Carolina 
Population Center (R24 HD050924) at The University of North Carolina at Chapel Hill for general support. Noah Kittner and Selena Elmer provided valuable research assistance. The opinions expressed herein are those of the authors and do not necessarily reflect the views of the sponsoring agency.

\section{Appendix A}

Table A1

Descriptive statistics for variables included in panel regression models

\begin{tabular}{|c|c|c|c|c|c|}
\hline Variable & $\mathbf{N}$ & Mean & $\begin{array}{l}\text { Standard } \\
\text { deviation }\end{array}$ & Minimum & Maximum \\
\hline \multicolumn{6}{|l|}{2007 Panel } \\
\hline Total fuel (kgs) & 451 & 463.18 & 332.89 & 0.00 & 1560.00 \\
\hline Fuelwood from forest (kgs) & 451 & 349.37 & 331.20 & 0.00 & 1500.00 \\
\hline Fuelwood from non-forest (kgs) & 451 & 99.12 & 200.34 & 0.00 & 1000.00 \\
\hline Crop residues (kgs) & 451 & 2.47 & 18.10 & 0.00 & 240.00 \\
\hline $\begin{array}{l}\text { Land use change from forest to woody } \\
\text { savannah }(1,000 \text { ha) }\end{array}$ & 451 & 2.87 & 3.50 & 0.06 & 9.12 \\
\hline $\begin{array}{l}\text { Land use change from forest to cropland } \\
(1,000 \text { ha) }\end{array}$ & 451 & 1.73 & 1.60 & 0.00 & 5.65 \\
\hline $\begin{array}{l}\text { Land use change from woody savannah to } \\
\text { cropland }(1,000 \text { ha) }\end{array}$ & 451 & 2.07 & 2.21 & 0.09 & 9.40 \\
\hline Forest owned by household (ha) & 451 & 0.34 & 0.63 & 0.00 & 4.86 \\
\hline $\begin{array}{l}\text { Agricultural land owned by household } \\
\text { (ha) }\end{array}$ & 451 & 1.33 & 1.26 & 0.00 & 15.00 \\
\hline Age of household head (years) & 451 & 44.15 & 15.67 & 18.00 & 112.00 \\
\hline Education of household head (years) & 451 & 4.50 & 3.59 & 0.00 & 18.00 \\
\hline Female headed household $(0=$ No; $1=$ Yes $)$ & 451 & 0.16 & 0.36 & 0.00 & 1.00 \\
\hline Household size (number of people) & 451 & 6.17 & 2.71 & 1.00 & 16.00 \\
\hline Total income (100,000 UgShs) & 451 & 61.26 & 77.04 & 0.00 & 998.97 \\
\hline Distance to nearest forest (minutes) & 451 & 33.48 & 42.35 & 0.00 & 240.00 \\
\hline \multicolumn{6}{|l|}{2012 Panel } \\
\hline Total fuel (kgs) & 451 & 499.01 & 356.87 & 0.00 & 2160.00 \\
\hline Fuelwood from forest (kgs) & 451 & 264.76 & 311.06 & 0.00 & 1500.00 \\
\hline Fuelwood from non-forest (kgs) & 451 & 200.02 & 242.56 & 0.00 & 1000.00 \\
\hline Crop residues (kgs) & 451 & 26.58 & 82.46 & 0.00 & 500.00 \\
\hline $\begin{array}{l}\text { Land use change from forest to woody } \\
\text { savannah }(1,000 \mathrm{ha})\end{array}$ & 451 & 1.87 & 2.69 & 0.04 & 8.41 \\
\hline $\begin{array}{l}\text { Land use change from forest to cropland } \\
(1,000 \text { ha })\end{array}$ & 451 & 0.46 & 0.44 & 0.00 & 1.46 \\
\hline $\begin{array}{l}\text { Land use change from woody savannah to } \\
\text { cropland }(1,000 \mathrm{ha})\end{array}$ & 451 & 3.15 & 2.51 & 0.00 & 6.98 \\
\hline Forest owned by household (ha) & 451 & 0.25 & 0.58 & 0.00 & 4.86 \\
\hline $\begin{array}{l}\text { Agricultural land owned by household } \\
\text { (ha) }\end{array}$ & 451 & 1.33 & 1.28 & 0.00 & 10.94 \\
\hline Age of household head (years) & 451 & 44.12 & 15.64 & 18.00 & 112.00 \\
\hline Education of household head (years) & 451 & 4.51 & 3.60 & 0.00 & 18.00 \\
\hline Female headed household $(0=$ No; $1=$ Yes $)$ & 451 & 0.15 & 0.36 & 0.00 & 1.00 \\
\hline
\end{tabular}




\begin{tabular}{lccccc}
\hline Variable & N & Mean & $\begin{array}{c}\text { Standard } \\
\text { deviation }\end{array}$ & Minimum & Maximum \\
\hline Household size (number of people) & 451 & 4.31 & 3.62 & 0.00 & 16.00 \\
\hline Total income (100,000 UgShs) & 451 & 148.94 & 156.20 & 0.00 & 1000.00 \\
\hline Distance to nearest forest (minutes) & 451 & 45.06 & 43.33 & 1.00 & 240.00 \\
\hline
\end{tabular}

Table A2

Descriptive statistics for variables included in probit regression models

\begin{tabular}{|c|c|c|c|c|c|}
\hline Variable & $\mathbf{N}$ & Mean & $\begin{array}{l}\text { Standard } \\
\text { deviation }\end{array}$ & Minimum & Maximum \\
\hline $\begin{array}{l}\text { Presence of acute respiratory } \\
\text { infection, } 0=\text { No; } 1=\text { Yes }\end{array}$ & 1807 & 0.16 & 0.37 & 0 & 1 \\
\hline Fuelwood from forest (100 kgs) & 1807 & 2.75 & 3.22 & 0 & 15 \\
\hline Charcoal from forest (100 kgs) & 1807 & 0.08 & 0.64 & 0 & 5 \\
\hline $\begin{array}{l}\text { Fuelwood from non-forest (100 } \\
\text { kgs) }\end{array}$ & 1807 & 1.93 & 2.40 & 0 & 10 \\
\hline Crop residues (100 kgs) & 1807 & 0.35 & 0.94 & 0 & 5 \\
\hline Total income (100,000 UgShs) & 1807 & 15.39 & 16.76 & 0 & 100 \\
\hline $\begin{array}{l}\text { Second youngest child (c.f. } \\
\text { youngest child) }\end{array}$ & 1807 & 0.11 & 0.31 & 0 & 1 \\
\hline $\begin{array}{l}\text { Third youngest child (c.f. youngest } \\
\text { child) }\end{array}$ & 1807 & 0.03 & 0.17 & 0 & 1 \\
\hline Primary cook (c.f. youngest child) & 1807 & 0.30 & 0.46 & 0 & 1 \\
\hline $\begin{array}{l}\text { Secondary cook (c.f. youngest } \\
\text { child) }\end{array}$ & 1807 & 0.22 & 0.41 & 0 & 1 \\
\hline Tertiary cook (c.f. youngest child) & 1807 & 0.15 & 0.36 & 0 & 1 \\
\hline $\begin{array}{l}\text { Cooking indoors with ventilation } \\
\text { (c.f. cooking outdoors) }\end{array}$ & 1807 & 0.74 & 0.44 & 0 & 1 \\
\hline $\begin{array}{l}\text { Cooking indoors with no } \\
\text { ventilation (c.f. cooking outdoors) }\end{array}$ & 1807 & 0.10 & 0.29 & 0 & 1 \\
\hline $\begin{array}{l}\text { Cooking on improved stove } \\
(0=\text { No; } 1=\text { Yes })\end{array}$ & 1807 & 0.18 & 0.38 & 0 & 1 \\
\hline Household size (number of people) & 1807 & 5.03 & 3.99 & 0 & 20 \\
\hline Age of head (years) & 1807 & 43.14 & 15.16 & 16 & 112 \\
\hline $\begin{array}{l}\text { Female headed household }(0=\text { No; } \\
1=\text { Yes })\end{array}$ & 1807 & 0.16 & 0.36 & 0 & 1 \\
\hline Education of head (years) & 1807 & 4.60 & 3.63 & 0 & 18 \\
\hline Bugoma site (c.f. Rwenzori) & 1807 & 0.23 & 0.42 & 0 & 1 \\
\hline Budongo site (c.f. Rwenzori) & 1807 & 0.46 & 0.50 & 0 & 1 \\
\hline
\end{tabular}

\section{References}

Acworth, J. Opportunities for PRIME/West initiatives in Hoima and Masindi Districts: Draft road map. USAID/DAI; Kampala, Uganda: 2005. Unpublished Report

Ahrends A, Burgess ND, Milledge SAH, Bulling MT, Fisher B, Smart JRC, Philip Clarke G, Mhoro BE, Lewis SL. Predictable waves of sequential forest degradation and biodiversity loss spreading 
from an African city. Proceedings of the National Academies of Science. 2010; 107(33):1455614561.

Arnold M, Köhlin G, Persson R. Woodfuels, livelihoods, and policy interventions: Changing perspectives. World Dev. 2005; 34(3):596-611.

Bailis R, Cowan A, Berrueta V, Masera O. Arresting the killer in the kitchen: The promises and pitfalls of commercializing improved cookstoves. World Dev. 2009; 37(10):1694-1705.

Bailis R, Ezzati M, Kammen D. Mortality and greenhouse gas impacts of biomass and petroleum energy futures in Africa. Science. 2005; 308(5718):98-103. [PubMed: 15802601]

Baland JM, Bardhan P, Das S, Mookherjee D, Sarkar R. The environmental impact of poverty: Evidence from firewood collection in rural Nepal. Economic Development and Cultural Change. 2010; 59(1):23-61. [PubMed: 20821892]

Barnes, D.; Krutilla, K.; Hyde, W. The urban energy transition: Energy, poverty and the environment in the developing world. World Bank; Washington, DC: 2002.

Brouwer ID, Horweg JC, Van Liere MJ. When households run out of fuel: Responses of rural households to decreasing fuelwood availability, Ntcheu District, Malawi. World Dev. 1997; 25(2): 255-266.

Chen L, Heerink N, van den Berg M. Energy consumption in rural China: A household model for three villages in Jiangxi Province. Ecological Economics. 2005; 58(2):407-420.

DeFries R, Hansen A, Turner BL, Reid R, Liu J. Land use change around protected areas: management to balance human needs and ecological function. Ecological Applications. 2007; 17(4):1031-1038. [PubMed: 17555216]

Dosier, R. Encyclopedia of energy. Vol. Volume 2. Elsevier Inc.; New York: 2004. Energy ladder in developing nations; p. 423-435.

Eckholm, EP. The other energy crisis, firewood. Worldwatch Institute; Washington, D.C.: 1975.

Edwards JHY, Langpap C. Startup costs and the decision to switch from firewood to gas fuel. Land Economics. 2005; 81(4):570-586.

Ezzati M, Lopez AD, Rodgers A, Vander Hoorn S, Murray CJL, Comparative Risk Assessment Collaborating Group. Selected major risk factors and global and regional burden of disease. Lancet. 2002; 360:1347-1361. [PubMed: 12423980]

Ezzati M, Kammen D. Indoor air pollution from biomass combustion and acute respiratory infections in Kenya: an exposure-response study. Lancet. 2001; 358:619-624. [PubMed: 11530148]

Foell W, Pachauri S, Spreng D, Zerriffi H. Household cooking fuels and technologies in developing economies. Energy Policy. 2011; 39:7487-7496.

Foley J. Sustainable woodfuel supplies from the dry tropical woodlands. ESMAP technical paper. 2001; 013:1-94.

Foley J, DeFries R, Asner G, Barford C, Bonan G, Carpenter S, et al. Global consequences of land use. Science. 2005; 309(570):570-574. [PubMed: 16040698]

Friedl MA, Sulla-Menashe D, Tan B, Schneider A, Ramankutty N, Sibley A, Huang X. MODIS Collection 5 global land cover: Algorithm refinements and characterization of new datasets. Remote Sensing of Environment. 2010; 114(1):168-182.

Fullerton D, Bruce N, Gordon S. Indoor air pollution from biomass fuel smoke is a major health concern in the developing world. Trans R Soc Trop Med Hyg. 2008; 102:843-851. [PubMed: 18639310]

GACC (Global Alliance for Clean Cookstoves). [Accessed 25 Nov. 2013] Data and statistics. 2013. http://www.cleancookstoves.org/resources/data-and-statistics/

Grieshop A, Marshall J, Kandlikar M. Health and climate benefits of cookstove replacement options. Energy Policy. 2011; 39:7530-7542.

Gundimeda H, Köhlin G. Fuel demand elasticities for energy and environmental policies: Indian sample survey evidence. Energy Economics. 2008; 30(2):517-546.

Gupta G, Köhlin G. Preferences for domestic fuel: Analysis with socio-economic factors and rankings in Kolkata, India. Ecological Economics. 2006; 57(1):107-121.

Heltberg R. Fuel switching: evidence from eight developing countries. Energy Economics. 2004; 26(5):869-887. 
Hiemstra-van der Horst GH, Hovorka A. Fuelwood: The "other" renewable energy source for Africa? Biomass Bioenergy. 2009; 33:1605-1616.

Jagger P, Shively G, Arinaitwe A. Circular migration, small-scale logging and household livelihoods in Uganda. Population and Environment. 2012; 34:235-256.

Jumbe C, Angelsen A. Modeling choice of fuel wood source among rural households in Malawi: A multinomial probit analysis. Energy Economics. 2011; 33(5):732-738.

Kandlikar, M.; Reynolds, CCO.; Greishop, AP. A perspective paper on black carbon mitigation as a response to climate change. Copenhagen Consensus Center; Copenhagen, Denmark: 2009.

Kavi Kumar KS, Viswanathan B. Changing structure of income indoor air pollution relationship in India. Energy Policy. 2007; 35(11):5496-5504.

Khundi F, Jagger P, Shively G, Sserunkuuma D. Income, poverty and charcoal production in western Uganda. Forest Policy and Economics. 2011; 13(3):199-205.

Lim SS, Vos T, Flaxman AD, Danaei G, Shibuya K, Adair-Rohani H, Degenhardt L. A comparative risk assessment of burden of disease and injury attributable to 67 risk factors and risk factor clusters in 21 regions, 1990-2010: a systematic analysis for the Global Burden of Disease Study 2010. Lancet. 2013; 380(9859):2224-2260. [PubMed: 23245609]

Lipper, L. Unyslva 202. FAO; 2000. Forest degradation and food security.

Macht, C.; Axinn, WG.; Ghimire, D. Household Energy Consumption: Community Context and the Fuelwood Transition. University of Michigan; Ann Arbor: 2007. Population Studies Center Research Report 07-629

MAAIF. Basic Facts on Agricultural Activities in Uganda. Ministry of Agriculture, Animal Industry and Fisheries; Kampala, Uganda: 1995.

Masera O, Ghilardi A, Drigo R, Trossero M. WISDOM: A GIS-based supply demand mapping tool for woodfuel management. Biomass Bioenergy. 2006; 30:618-37.

Mishra V, Dai X, Smith KR, Mika L. Maternal exposure to biomass smoke and reduced birth weight in Zimbabwe. Annals of Epidemiology 2004. 2004; 14:740-747.

Naughton-Treves L, Kammen D, Chapman C. Burning biodiversity: Woody biomass use by commercial and subsistence groups in western Uganda's forests. Biological Conservation. 2007; 134:232-241.

Nkambwe M, Sekhwela M. Utilization characteristics and importance of woody biomass resources on the rural-Urban fringe in Botswana. Environmental Management. 2006; 37(2):281-296. [PubMed: 16391967]

Nsita, SA. Decentralization and forest management in Uganda. In: Colfer, CJP.; Capistrano, D., editors. The Politics of Decentralization: Forests, Power and People. Earthscan; London, UK: 2005.

Nzita, R.; Miwampa, M. Peoples and cultures of Uganda. Fountain Publishers; Kampala, Uganda: 1993.

Omeja PA, Chapman CA, Obua J, Lwanga JS, Jacob AL, Wanyama F, Mugenyi R. Intensive tree planting facilitates tropical forest biodiversity and biomass accumulation in Kibale National Park, Uganda. Forest Ecology and Management. 2011; 261(3):703-709.

Openshaw K. Supply of woody biomass, especially in the tropics: Is demand outstripping sustainable supply? International Forestry Review. 2011; 13(4):487-499.

Pandey S, Yadama GN. Community development programs in Nepal: A test of diffusion of innovation theory. The Social Service Review. 1992; 66(4):582-597.

Pattanayak SK, Pfaff A. Behavior, Environment, and Health in Developing Countries: Evaluation and Valuation. Annual Review of Resource Economics. 2009; 1(1):183-217.

Pfeifer M, Platts P, Burgess N, Swetnam R, Willcock S, Lewis S, Marchant R. Land use change and carbon fluxes in East Africa quantified using earth observation data and field measurements. Environmental Conservation. 2012:1-12.

Ramanathan V, Carmichael G. Global and regional climate changes due to black carbon. Nature Geoscience. 2008; 1:221-227. 
Rehfuess EA, Briggs DJ, Joffe M, Best N. Bayesian modelling of household solid fuel use: Insights towards designing effective interventions to promote fuel switching in Africa. Environmental Research. 2010; 110(7):725-732. [PubMed: 20655517]

Shively G, Jagger P, Sserunkuuma D, Arinaitwe A, Chibwana C. Profits and margins along Uganda's charcoal value chain. International Forestry Review. 2011; 12(3):271-284.

Sinton JE, Smith KR, Peabody JW, Yaping L, Xiliang Z, Edwards R, et al. An assessment of programs to promote improved household stoves in China. Energy for Sustainable Development. 2004; 8(3): 33-52.

Smith KR. National burden of disease in India from indoor air pollution. Proceedings of the National Academy of Sciences. 2000; 97:13286-13293.

Smith KR, Balakrishnan K. Mitigating climate, meeting MDGs, and moderating chronic disease: The health co-benefits landscape. Commonwealth Health Minister's Update. 2009:59-65.

Smith KR, Jerrett M, Anderson HR, Burnett RT, Stone V, Derwent R, et al. Public health benefits of strategies to reduce greenhouse-gas emissions: health implications of short-lived greenhouse pollutants. Lancet. 2009; 374(9707):2091-2103. [PubMed: 19942276]

Smeets E, Faaij A. Bioenergy potentials from forestry in 2050. Climatic Change. 2007; 81:353-390.

Sreeramareddy CT, Shidhaye RR, Sithaikumar N. Association between biomass fuel use and maternal report of child-size at birth - An analysis of 2005-2006 India Demographic and Health Survey. BMC Public Health. 2011; 11:403. [PubMed: 21619613]

Türker MF, Kaygusuz K. Investigation of the variables effects on fuelwood consumption as an energy source in forest villages of Turkey. Energy Conversion and Management. 2001; 42(10):12151227.

Turyareeba, P.; Drichi, P.; UNEP Collaborating Centre on Energy and Environment. [Accessed 02/10/12] Plan for development of Uganda's Biomass Energy Strategy. 2001. p. 1-37.at http:// uneprisoe.org/SEAF/PlanDevelopBioEnergyStrategy.pdf

UBOS. 2002 Uganda population and housing census. Uganda Bureau of Statistics; Kampala, Uganda: 2006.

UNEP and WMO. Integrated assessment of black carbon and tropospheric ozone: summary for decision Makers. United Nations Environment Program; Nairobi, Kenya: 2011.

Vintrou E, Desbrosse A, Bégué A, Traoré S, Baron C, Lo Seen D. Crop area mapping in West Africa using landscape stratification of MODIS time series and comparison with existing global land products. International Journal of Applied Earth Observation and Geoinformation. 2012; 14(1):8393.

Vlosky R, Smithhart R. A brief global perspective on biomass for bioenergy and biofuels. Journal of Tropical Forestry and Environment. 2011; 1(1):1-13.

WHO. Fuel for life: Household energy and health. World Health Organization; Geneva: 2006.

Webb, P. Achieving food and nutrition security: Lessons learned from the Integrated Food Security Program (IFSP), Mulanje, Malawi. Feinstein International Center, Tufts University; Boston, MA: 2011. 


\section{Highlights}

- Land use change affects the quality, quantity and type of biomass fuels rural households use.

- Use of fuelwood from non-forest areas leads to an increase in ARI for children under 5.

- Use of crop residues leads to a decrease in ARI for children under 5. 


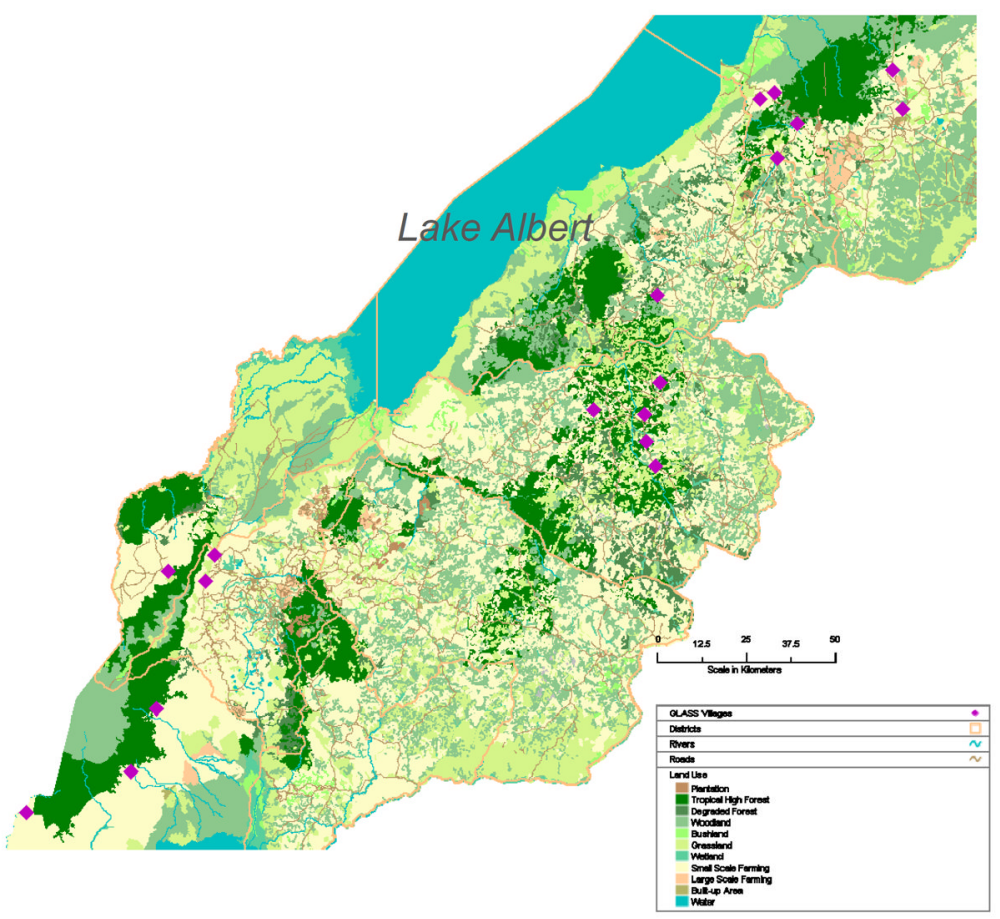

Figure 1.

Study sites in western Uganda (purple diamonds denote village centroids) 

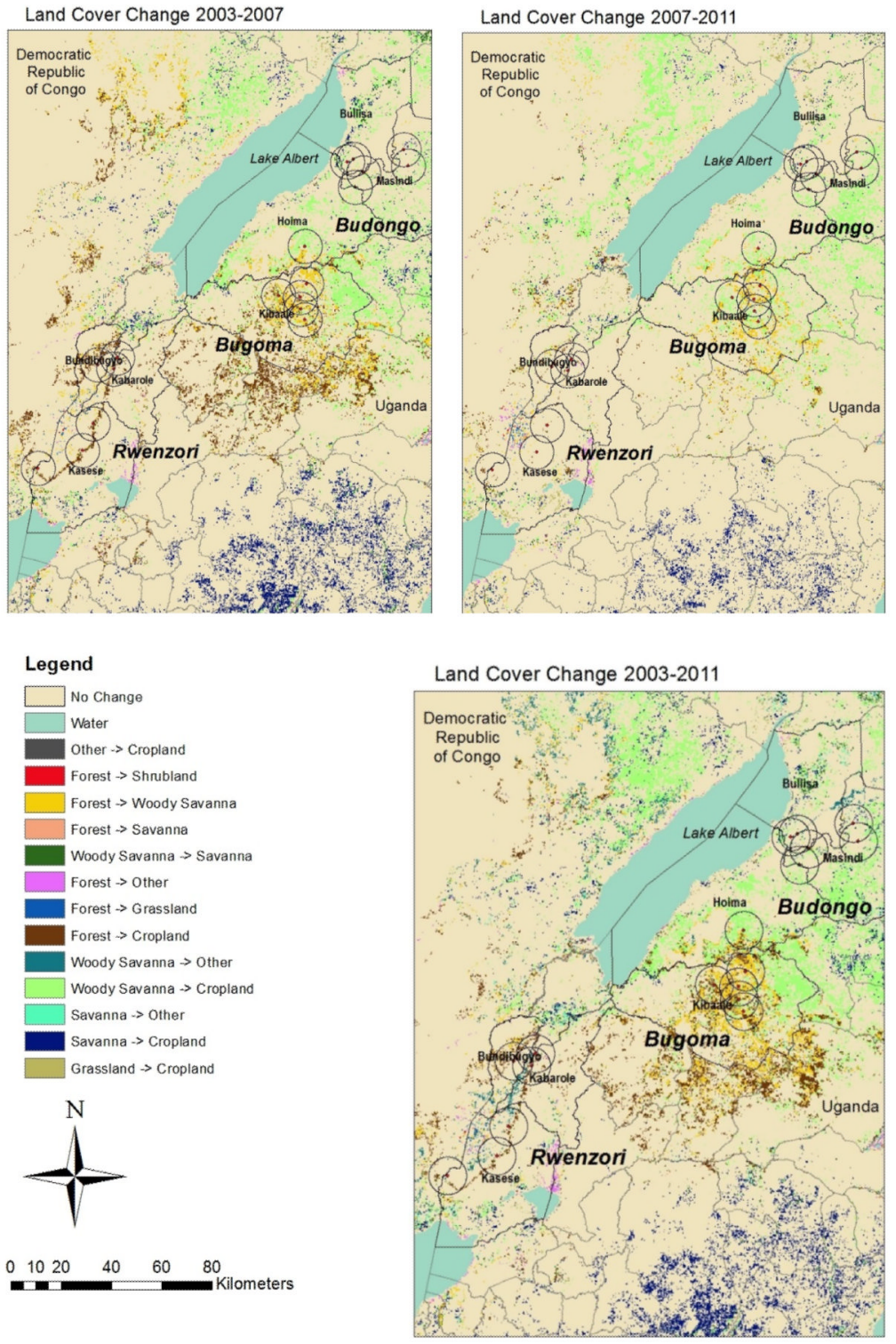

Figure 2.

Land cover change 2003-2011, Uganda (circles denote $5 \mathrm{~km}$ buffers around village centroids) 
Table 1

Woody biomass density by land use $e^{a, b, c}$

\begin{tabular}{|c|c|c|}
\hline Land cover [use] & Ungazetted land $^{d}$ (hectares) & Available (t/ha) \\
\hline Tropical high forest & 174,800 & 224.0 \\
\hline Tropical high forest (degraded) & 175,900 & 113.0 \\
\hline Woodlands & $2,601,800$ & 29.9 \\
\hline Broadleaved plantations & 12,200 & 75.7 \\
\hline Softwood plantations & 700 & 147.1 \\
\hline Large-scale farmlands & 66,200 & 0.0 \\
\hline Subsistence farmlands & $7,902,140$ & 12.7 \\
\hline Bush lands & 559,520 & 12.3 \\
\hline Grass lands & $2,755,770$ & 11.3 \\
\hline \multicolumn{3}{|l|}{ All values for air dried wood. } \\
\hline \multicolumn{3}{|c|}{${ }^{b}$ Adapted from Turyareeba, Drichi and UNEP (2001). } \\
\hline
\end{tabular}


Table 2

Land use within a $5 \mathrm{~km}$ radius of village centroids, percent

\begin{tabular}{|c|c|c|c|c|c|c|}
\hline & 2003 & 2007 & 2011 & Percent change 2003-2007 & Percent change 2007-2011 & Percent change 2003-2011 \\
\hline \multicolumn{7}{|l|}{ Rwenzori Site $(\mathrm{N}=6)$} \\
\hline Forest & 12.5 & 13.2 & 13.2 & 5.6 & 0.0 & 5.6 \\
\hline Woody savannah & 25.3 & 23.4 & 17.4 & -7.5 & -25.6 & -31.2 \\
\hline Savannah & 2.0 & 1.9 & 0.7 & -5.0 & -63.2 & -65.0 \\
\hline Cropland & 60.0 & 61.2 & 68.7 & 2.0 & 12.3 & 14.5 \\
\hline \multicolumn{7}{|l|}{ Bugoma Site $(\mathrm{N}=6)$} \\
\hline Forest & 55.1 & 24.3 & 11.9 & -55.9 & -51.0 & -78.4 \\
\hline Woody savannah & 26.3 & 41.8 & 40.7 & 58.9 & -2.6 & 54.8 \\
\hline Savannah & 0 & 0.5 & 0 & NA & -100.0 & 0 \\
\hline Cropland & 18.6 & 33.3 & 47.4 & 79.0 & 42.3 & 154.8 \\
\hline \multicolumn{7}{|l|}{ Budongo site $(\mathrm{N}=6)$} \\
\hline Forest & 61.3 & 49.5 & 57.2 & -19.2 & 15.6 & -6.7 \\
\hline Woody savannah & 3.8 & 2.3 & 0.4 & -39.5 & -82.6 & -89.5 \\
\hline Savannah & 0 & 0.1 & 0.1 & NA & 0.0 & NA \\
\hline Cropland & 33.8 & 47.2 & 41.3 & 39.6 & -12.5 & 22.2 \\
\hline \multicolumn{7}{|l|}{ All $(\mathrm{N}=18)$} \\
\hline Forest & 43.0 & 29.0 & 27.4 & -32.6 & -5.5 & -36.3 \\
\hline Woody savannah & 18.5 & 22.5 & 19.5 & 21.6 & -13.3 & 5.4 \\
\hline Savannah & 0.7 & 0.8 & 0.3 & 14.3 & -62.5 & -57.1 \\
\hline Cropland & 37.4 & 47.2 & 52.5 & 26.2 & 11.2 & 40.4 \\
\hline
\end{tabular}


Table 3

Fuel use per household by type and source (kgs) and time to forest (minutes) ${ }^{a}$

\begin{tabular}{|c|c|c|c|c|}
\hline & \multicolumn{2}{|c|}{ Full sample } & \multicolumn{2}{|c|}{ Matched panel } \\
\hline & 2007 & 2012 & 2007 & 2012 \\
\hline \multicolumn{5}{|l|}{ Rwenzori site } \\
\hline Fuelwood from forest (kgs) & $487.2(353.0)$ & $360.7 * * *(338.5)$ & $495.8(359.9)$ & $360.7 * * *(338.5)$ \\
\hline Charcoal (kgs) & $14.0(82.0)$ & $9.6(68.0)$ & $15.9(87.5)$ & $9.6(68.0)$ \\
\hline Fuelwood from non-forest areas (kgs) & $88.9(212.2)$ & $198.8^{* * *}(238.6)$ & $92.6(217.3)$ & $198.8 * * *(238.6)$ \\
\hline Crop residue (kgs] & $1.9(14.6)$ & $14.8^{* * *}(51.4)$ & $2.2(15.6)$ & $14.8^{* * *}(51.4)$ \\
\hline Total volume of fuel (kgs) & $591.9(359.4)$ & $583.9(339.6)$ & $606.6(367.1)$ & $583.9(339.6)$ \\
\hline Distance to forest (minutes) & $57.0(50.7)$ & $73.3^{* * * *}(50.1)$ & $55.3(49.3)$ & $73.3^{* * *}(50.1)$ \\
\hline $\mathrm{N}$ & 170 & 154 & 154 & 154 \\
\hline \multicolumn{5}{|l|}{ Bugoma } \\
\hline Fuelwood from forest (kgs) & $333.5(294.7)$ & $241.9 * *(278.4)$ & $323.3(301.9)$ & $241.9^{* *}(278.4)$ \\
\hline Charcoal (kgs) & $15.1(84.4)$ & $12.2(77.3)$ & $16.6(88.2)$ & $12.2(77.3)$ \\
\hline Fuelwood from non-forest areas (kgs) & $82.7(180.6)$ & $247.8^{* * * *}(260.8)$ & $85.6(185.2)$ & $247.8 * * *(260.8)$ \\
\hline Crop residue (kgs) & $0.1(1.1)$ & $4.2^{* *}(25.7)$ & $0.1(1.2)$ & $4.2 * *(25.7)$ \\
\hline Total volume of fuel (kgs) & $420.5(289.1)$ & $506.3 * *(362.1)$ & $425.6(296.7)$ & $506.3^{* *}(362.1)$ \\
\hline Distance to forest (minutes) & $11.4(13.1)$ & $21.3^{* * *}(20.9)$ & $11.2(13.0)$ & $21.3^{* * *}(20.9)$ \\
\hline $\mathrm{N}$ & 173 & 161 & 161 & 161 \\
\hline \multicolumn{5}{|l|}{ Budongo site } \\
\hline Fuelwood from forest (kgs) & $247.7(281.2)$ & $193.0 *(289.0)$ & $242.5(271.3)$ & $181.8^{*}(287.3)$ \\
\hline Charcoal (kgs) & $13.5(79.3)$ & $4.2(45.7)$ & $3.6(42.7)$ & 0 \\
\hline Fuelwood from non-forest areas (kgs) & $127.2(203.8)$ & $141.7(208.7)$ & $132.8(209.8)$ & $154.1(223.3)$ \\
\hline Crop residue (kgs) & $6.3(34.0)$ & $61.0 * * *(121.4)$ & $5.6(28.2)$ & $65.1 * * *(127.8)$ \\
\hline Total volume of fuel (kgs) & $394.7(301.4)$ & $400.0(331.8)$ & $384.5(273.1)$ & $400.9(345.7)$ \\
\hline Distance to forest (minutes) & $35.5(44.6)$ & $40.2(35.6)$ & $35.9(43.6)$ & $41.8(36.4)$ \\
\hline $\mathrm{N}$ & 171 & 238 & 139 & 139 \\
\hline \multicolumn{5}{|l|}{ All sites } \\
\hline Fuelwood from forest (kgs) & $352.1(326.1)$ & $253.9^{* * *}(308.1)$ & $356.3(330.3)$ & $263.8^{* * *}(310.6)$ \\
\hline Charcoal (kgs) & $14.2(81.8)$ & $8.1(62.7)$ & $12.4(76.9)$ & $7.6(60.7)$ \\
\hline Fuelwood from non-forest areas (kgs) & $99.5(199.8)$ & $188.5^{* * *}(237.1)$ & $102.5(204.8)$ & $202.5^{* * *}(244.5)$ \\
\hline Crop residue (kgs) & $2.7(21.4)$ & $31.6^{* * *}(89.0)$ & $2.5(18.2)$ & $26.4 * * *(82.2)$ \\
\hline Total volume of fuel (kgs) & $468.6(329.2)$ & $482.1(351.0)$ & $473.7(329.2)$ & $500.3(356.1)$ \\
\hline Distance to forest (minutes) & $34.5(43.8)$ & $43.9 * * *(42.0)$ & $33.6(42.4)$ & $45.2 * * *(43.3)$ \\
\hline $\mathrm{N}$ & 514 & 553 & 454 & 454 \\
\hline
\end{tabular}

$a_{*, * *, * * * \text { means }} 2007$ and 2012 data are statistically significantly different at the $10 \%, 5 \%$, and $1 \%$ levels respectively. 
Table 4

Land use change and fuel use, panel regression results ${ }^{a, b}$

\begin{tabular}{|c|c|c|c|c|}
\hline & Total fuel (kgs) & $\begin{array}{l}\text { Fuelwood from forest } \\
\text { (kgs) }\end{array}$ & $\begin{array}{l}\text { Fuel wood from non- } \\
\text { forest (kgs) }\end{array}$ & Crop residues (kgs) \\
\hline \multirow{2}{*}{$\begin{array}{l}\text { Land use change from forest to woody } \\
\text { savannah }(1,000 \mathrm{ha})\end{array}$} & -28.067 & 6.121 & $-39.558^{* * *}$ & 0.318 \\
\hline & $(20.84)$ & $(18.00)$ & $(15.01)$ & $(2.52)$ \\
\hline \multirow{2}{*}{$\begin{array}{l}\text { Land use change from forest to cropland } \\
(1,000 \text { ha) }\end{array}$} & $-42.645^{*}$ & -28.756 & -15.297 & -1.913 \\
\hline & $(21.79)$ & (18.76) & $(12.95)$ & $(3.88)$ \\
\hline \multirow{2}{*}{$\begin{array}{l}\text { Land use change from woody savannah to } \\
\text { cropland (1,000 ha) }\end{array}$} & $-22.579^{*}$ & -16.571 & -12.95 & -1.47 \\
\hline & $(13.41)$ & $(11.53)$ & $(9.92)$ & $(1.53)$ \\
\hline \multirow[t]{2}{*}{ Fuelwood from forest (kgs) } & - & - & $-0.234 * * *$ & 0.006 \\
\hline & & & $(0.03)$ & $(0.01)$ \\
\hline \multirow[t]{2}{*}{ Fuelwood from non-forest (kgs) } & - & $-0.416^{* * *}$ & - & 0 \\
\hline & & $(0.04)$ & & $(0.01)$ \\
\hline \multirow[t]{2}{*}{ Crop residues (kgs) } & - & 0.006 & 0.094 & - \\
\hline & & $(0.15)$ & $(0.13)$ & \\
\hline \multirow[t]{2}{*}{ Forest owned by household (ha) } & 28.749 & $45.670^{* *}$ & -16.337 & 1.856 \\
\hline & $(23.52)$ & $(23.13)$ & $(10.73)$ & $(1.41)$ \\
\hline \multirow[t]{2}{*}{ Agricultural land owned by household (ha) } & 8.019 & 11.986 & 3.031 & -1.963 \\
\hline & $(10.96)$ & $(9.87)$ & $(7.59)$ & $(1.39)$ \\
\hline \multirow[t]{2}{*}{ Age of household head (years) } & 0.371 & 0.235 & 0.444 & -0.017 \\
\hline & $(0.71)$ & $(0.64)$ & $(0.47)$ & $(0.13)$ \\
\hline \multirow[t]{2}{*}{ Education of household head (years) } & -2.099 & -2.685 & 1.729 & 0.05 \\
\hline & $(3.39)$ & $(3.00)$ & $(2.24)$ & $(0.4)$ \\
\hline \multirow[t]{2}{*}{ Female headed household $(0=\mathrm{No} ; 1=\mathrm{Yes})$} & -17.504 & -6.099 & -2.95 & -1.353 \\
\hline & $(30.7)$ & $(27.13)$ & $(19.93)$ & $(5.86)$ \\
\hline \multirow[t]{2}{*}{ Household size (number of people) } & $28.397 * *$ & $24.821 * *$ & $18.029 * *$ & $-9.564 * * *$ \\
\hline & $(13.85)$ & $(12.06)$ & $(8.4)$ & $(3.12)$ \\
\hline \multirow[t]{2}{*}{ Household size $\mathrm{x} 2$} & -0.173 & 0.012 & -0.656 & $0.536^{* *}$ \\
\hline & $(1.01)$ & $(0.96)$ & 0.58 & $(0.22)$ \\
\hline \multirow[t]{2}{*}{ Total income $(100,000 \mathrm{UgShs})$} & $4.860^{* * *}$ & $3.556^{* * *}$ & $1.552 * * *$ & 0.480 \\
\hline & $(0.12)$ & $(0.12)$ & $(0.06)$ & $(0.04)$ \\
\hline \multirow[t]{2}{*}{ Distance to nearest forest (minutes) } & $-0.607 * *$ & $-0.483^{*}$ & $-0.434 * *$ & $0.131^{* *}$ \\
\hline & $(0.29)$ & $(0.28)$ & $(0.18)$ & $(0.06)$ \\
\hline \multirow[t]{2}{*}{ Constant } & $472.779^{* * *}$ & $369.733 * * *$ & $136.001 * * *$ & $31.195^{* *}$ \\
\hline & $(77.51)$ & $(65.77)$ & $(51.22)$ & $(12.34)$ \\
\hline $\mathrm{N}$ & 902 & 902 & 902 & 902 \\
\hline Wald chi2 & 184.48 & 401.60 & 230.51 & 149.73 \\
\hline
\end{tabular}




\begin{tabular}{|l|l|l|l|l|}
\hline & Total fuel (kgs) & $\begin{array}{l}\text { Fuelwood from forest } \\
\text { (kgs) }\end{array}$ & $\begin{array}{l}\text { Fuel wood from non- } \\
\text { forest (kgs) }\end{array}$ & Crop residues (kgs) \\
\hline R squared (within) & 0.0564 & 0.1424 & 0.1814 & 0.1753 \\
\hline R squared (between) & 0.2803 & 0.3983 & 0.1938 & 0.4162 \\
\hline R squared (overall) & 0.1797 & 0.2842 & 0.1880 & 0.2976 \\
\hline
\end{tabular}

${ }^{a}$ Coefficients for village level dummy variables not reported.

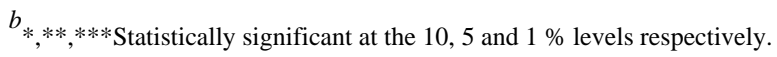


Table 5

Volume of fuel consumed by household and presence of acute respiratory infection (self or mother reported cough and trouble breathing) during two weeks prior to interview ${ }^{a, b}$

\begin{tabular}{|c|c|c|c|c|c|c|}
\hline \multirow[b]{2}{*}{ Volume } & \multicolumn{2}{|c|}{ All } & \multicolumn{2}{|c|}{ Children under 5} & \multicolumn{2}{|c|}{ Adult Cooks } \\
\hline & No ARI & ARI & No ARI & ARI & No ARI & ARI \\
\hline Total fuel, kgs & $508.1(247.8)$ & $524.7(368.6)$ & $506.2(352.6)$ & $553.9(355.8)$ & $508.7(346.2)$ & $457.8(390.3$ \\
\hline Fuelwood from forest, kgs & $273.4(322.1)$ & $270.3(317.3)$ & $280.7(318.4)$ & $285.9(317.5)$ & $270.8(232.5)$ & $234.8(317.6)$ \\
\hline Charcoal from forest, kgs & $8.4(64.0)$ & $8.4(64.0)$ & $11.2(73.7)$ & $7.2(59.3)$ & $7.4(60.2)$ & $11.1(74.1)$ \\
\hline Fuelwood from non-forest, kgs & $189.1 * *(238.8)$ & $223.8(253.4)$ & $182.5^{* * * *}(224.7)$ & $238.4(258.7)$ & $191.4(243.7)$ & $190.4(238.8)$ \\
\hline Crop residues, kgs & $37.3 * *(97.6)$ & $22.1(66.1)$ & $31.8(92.4)$ & $22.4(65.2)$ & $39.1 *(99.4)$ & $21.5(687.5)$ \\
\hline $\mathrm{N}$ & 1527 & 296 & 399 & 206 & 1128 & 90 \\
\hline \multicolumn{7}{|l|}{ Shares } \\
\hline Fuelwood from forest, $\%$ & $53.0(41.3)$ & $51.7(39.3)$ & $54.5(40.5)$ & $52.0(38.7)$ & $52.0(41.6)$ & $51.0(40.7)$ \\
\hline Charcoal, $\%$ & $1.1(8.2)$ & $0.9(6.7)$ & $1.2(7.9)$ & $0.8(6.8)$ & $1.0(8.4)$ & $1.0(6.6)$ \\
\hline Fuelwood from non-forest, $\%$ & $37.6 * *(38.6)$ & $43.1(38.5)$ & $37.6(38.0)$ & $42.6(38.0)$ & $37.6(38.8)$ & $44.3(39.7)$ \\
\hline Crop residues, $\%$ & $8.4 * * *(20.0)$ & $4.3(12.6)$ & $6.7(18.1)$ & $4.5(13.4)$ & $8.9^{* *}(20.6)$ & $3.4(10.5)$ \\
\hline $\mathrm{N}$ & 1438 & 274 & 378 & 194 & 1060 & 80 \\
\hline
\end{tabular}




\section{Table 6}

Determinants of acute respiratory infection (ARI) in children under 5 and adults involved in cooking ${ }^{a, b}$

\begin{tabular}{|c|c|c|c|c|c|c|}
\hline & \multicolumn{2}{|l|}{ All } & \multicolumn{2}{|c|}{ Children under 5} & \multicolumn{2}{|c|}{ Adults } \\
\hline & Estimated coefficient & Marginal effect & Estimated coefficient & Marginal effect & Estimated coefficient & Marginal effect \\
\hline Fuelwood from forest (100 kgs) & $0.012(0.013)$ & 0.0024 & $0.032 *(0.019)$ & 0.0107 & $-0.008(0.021)$ & -0.0010 \\
\hline Fuelwood from non-forest (100 kgs) & $0.037 * *(0.017)$ & 0.0074 & $0.071 * * *(0.026)$ & 0.024 & $0.004(0.024)$ & 0.0005 \\
\hline Crop residues $100(\mathrm{kgs})$ & $-0.108^{* *}(0.051)$ & -0.0218 & $-0.118 *(0.069)$ & -0.039 & $-0.112(0.073)$ & -0.0147 \\
\hline $\begin{array}{l}\text { Second youngest child (c.f. youngest } \\
\text { child) }\end{array}$ & $-0.201 *(0.118)$ & -0.0705 & $-0.198 *(0.120)$ & -0.0668 & - & - \\
\hline $\begin{array}{l}\text { Third youngest child (c.f. youngest } \\
\text { child) }\end{array}$ & $-0.490 * *(0.200)$ & -0.1604 & $-0.504 * *(0.207)$ & -0.1580 & - & - \\
\hline Primary cook (c.f. youngest child) & $-0.920 * * *(0.101)$ & -0.2613 & - & - & - & - \\
\hline $\begin{array}{l}\text { Cooking indoors with no ventilation } \\
\text { (c.f. cooking outdoors) }\end{array}$ & $-0.172(0.168)$ & -0.0348 & $-0.087(0.241)$ & -0.0289 & $-0.194(0.234)$ & -0.0253 \\
\hline $\begin{array}{l}\text { Cooking on improved stove }(0=\mathrm{No} ; \\
1=\text { Yes })\end{array}$ & $-0.06(0.113)$ & -0.0121 & $0.11(0.160)$ & 0.0365 & $-0.216(0.176)$ & -0.0283 \\
\hline Household size (number of people) & $0.085^{* * *}(0.031)$ & 0.0173 & $0.139 * * *(0.045)$ & 0.0461 & $0.027(0.047)$ & 0.0036 \\
\hline Household size $\mathrm{x} 2$ & $-0.008 * * *(0.002)$ & -0.0017 & $-0.012 * * *(0.003)$ & -0.0039 & $-0.004(0.004)$ & -0.0006 \\
\hline Age of head (years) & $0.004(0.003)$ & 0.0009 & $0.008 *(0.005)$ & 0.0025 & $0.001(0.004)$ & 0.0001 \\
\hline $\begin{array}{l}\text { Female headed household }(0=\text { No; } \\
1=\text { Yes })\end{array}$ & $-0.056(0.123)$ & -0.0113 & $-0.361 *(0.203)$ & -0.1201 & $0.136(0.145)$ & 0.0178 \\
\hline Log-likelihood/Pseudo log-likelihood & -656.35 & & -350.56 & & -295.79 & \\
\hline
\end{tabular}

